DE

M E D I C I N A

T R O P I C A L

$\mathrm{DE}$

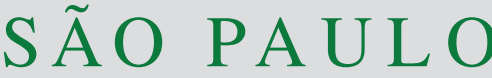

JOURNAL OF THE SÃO PAULO INSTITUTE OF TROPICAL MEDICINE

'Universidad de la República, Facultad de Medicina, Instituto de Higiene,

Departamento de Bacteriología y Virología, Montevideo, Uruguay

2Departamento de Laboratorios de Salud

Pública, Montevideo, Uruguay

Correspondence to: Felipe Schelotto Universidad de la República, Facultad de Medicina, Instituto de Higiene, Departamento de Bacteriología y Virología, Alfredo Navarro, 3051, 11600, Montevideo, Uruguay

Tel: +598 24875795, +59899166825

E-mail: felipe@ higiene.edu.uy

Received: 30 September 2019

Accepted: 6 December 2019

\section{Presence of genes encoding enterotoxins in Staphylococcus aureus isolates recovered from food, food establishment surfaces and cases of foodborne diseases}

\author{
Virginia Machado', Lorena Pardo', Dianna Cuello', Guillermina Giudice', \\ Patricia Correa Luna1, Gustavo Varela ${ }^{1}$, Teresa Camou ${ }^{\circledR 2}{ }^{2}$, Felipe Schelotto ${ }^{\left({ }^{1}\right.}$
}

\section{ABSTRACT}

The aim of this study was to describe the microbiological characteristics and profile of genes encoding enterotoxins in 95 Staphylococcus aureus isolates obtained between April 2011 and December 2014 from foodstuffs, persons and surfaces of retail food stores. After microbiological identification and antimicrobial susceptibility testing, polymerase chain reactions (PCR) were performed, targeting sea, seb, sec, sed and see genes that code for classical enterotoxins (ET) A-E, and three additional genes: seg, seh and sei, coding for so-called "new enterotoxins" G, $\mathrm{H}$ and I. The isolates were characterized by Pulsed Field Gel Electrophoresis (PFGE), and five selected isolates were further analyzed through Multi Locus Sequence Typing (MLST). It is noteworthy that $54.7 \%$ of the examined isolates harbored one or more of the investigated ET gene types. Most positive isolates carried more than one ET gene up to five types; seg was the most frequent ET gene, followed by sei. Five enterotoxin-coding isolates also coded for some antimicrobial resistance genes. Two of them, and four additional non-enterotoxic isolates carried erm genes expressing inducible clindamycin resistance. PFGE-types were numerous and diverse, even among enterotoxin-coding strains, because most isolates did not belong to known foodborne outbreaks and the sampling period was long. MLST profiles were also varied, and a new ST 3840 was described within this species. ST 88 and ST 72 enterotoxin-coding isolates have been identified in other regions in association with foodborne outbreaks. This manuscript reports the first systematic investigation of enterotoxin genes in $S$. aureus isolates obtained from foodstuffs and infected people in Uruguay.

KEYWORDS: Staphylococcus aureus. Enterotoxin genes. Foods. Antimicrobial resistance. Multi Locus Sequence Typing. Pulsed Field Gel Electrophoresis.

\section{INTRODUCTION}

Foodborne diseases include a broad group of illnesses caused by contaminated food or water intake. Although digestive manifestations are usually mild and selflimited, severe cases can occur, and sequelae may result. Infectious etiology is the most frequent. Common bacterial agents are Salmonella enterica, Shigella spp, Campylobacter jejuni, Clostridium botulinum, diarrheagenic Escherichia coli, Yersinia enterocolitica and Staphylococcus aureus, among others ${ }^{1}$.

$S$. aureus is a Gram-positive coccus that belongs to the human microbiota, but can also be responsible for multiple disease conditions, including cases of "food poisoning" due to its capacity of producing heat stable enterotoxins. These are short chain proteins produced in the food when S. aureus proliferates, and can cause disease in spite of correct meal cooking. Once ingested, enterotoxins soon produce 
the sudden onset of vomiting, abdominal pain and diarrhoea. In vulnerable groups such as the elderly and children, complications may occur. More than 20 enterotoxins and related superantigens have been described, but not all of them have an emetic effect. Those capable of producing intense vomiting in primates are ETA, ETB, ETC, ETD, ETE, ETG, ETI, ETR and ETT2 ${ }^{2}$. The other enterotoxins are known as ET-like toxins (ETL or ET/L) and this group includes the toxic shock syndrome toxin (TSST) ${ }^{3}$. The enterotoxin-coding genes are usually carried in mobile and transmissible genetic elements as phages, transposons or plasmids; a defined group of genes (seg, sei, seo, sem, sen) can be located in $\mathrm{vSa} \beta$ genomic island of $S$. aureus $^{3}$. This EGC operon (Enterotoxin Gene Cluster) may also include other enzyme- and toxin-coding sequences ${ }^{4-8}$.

As there were no studies in Uruguay on circulating staphylococcal enterotoxins, we decided to describe the microbiological characteristics of $S$. aureus isolates from foodstuffs, persons and surfaces of food establishments; to define if they carried enterotoxin-coding genes, and their types; to examine the antimicrobial susceptibility profile of all the isolates, and their comparative genome characteristics through SmaI-PFGE and MLST.

\section{MATERIALS AND METHODS}

\section{Gathering of isolates}

Ninety-five bacterial cultures previously identified as S. aureus were received from April 2011 to December 2014. They derived from food samples taken by public food control institutions, and from food processing and selling stores examined by private laboratories. No food or clinical sample was directly analysed. Forty-nine isolates were collected from surfaces and environment of food establishments; 40 from foodstuffs; four isolates were also obtained from food handlers and two from clients of a grocery store. Two food isolates were known to come from cheese and chicken salad, respectively. One isolate was obtained from cheese involved in a small family outbreak, and a related isolate was cultured from the store that sold the cheese. All received cultures were confirmed to be $S$. aureus by classical phenotypic assays. After spread-plating on blood agar, obtained colonies were examined through catalase, tube coagulase and DNase tests ${ }^{9}$; commercial DNase agar C/COL with methyl green was employed (BIOKEY lab. S.A. Uruguay).

\section{Antimicrobial susceptibility testing}

Antimicrobial susceptibility was determined according to conventional Kirby \& Bauer technique, modified as defined by Clinical \& Laboratory Standards Institute (CLSI) guidelines ${ }^{10}$. Cefoxitin, clindamycin, erythromycin, ciprofloxacin, sulfamethoxazole-trimethoprim and gentamicin were tested. The erythromycin and clindamycin discs were closely placed 15 to $25 \mathrm{~mm}$ apart, for detecting clindamycin-inducible resistance when a $\mathrm{D}$ zone could be observed ${ }^{11}$. After $18-24 \mathrm{~h}$ incubation at $35^{\circ} \mathrm{C}$, the inhibition zones diameters were measured and results were interpreted as susceptible (S), Intermediate (I) or Resistant (R). The clindamycin resistance was reported as inducible when a D zone was visible, or constitutive when $\mathrm{R}$ size zones surrounded both antibiotic discs.

\section{DNA extraction}

Three or four colonies of $S$. aureus were suspended in $100 \mu \mathrm{L}$ of a $1 \mathrm{U} / \mu \mathrm{L}$ solution of Achromopeptidase enzyme (Sigma-Aldrich, St. Louis, MO.). They were exposed to $94{ }^{\circ} \mathrm{C}$ for $10 \mathrm{~min}$ and for further $10 \mathrm{~min}$ at 55 ${ }^{\circ} \mathrm{C}$. The mixture was then centrifuged at $10,000 \mathrm{~g} ; 80 \mu \mathrm{L}$ of the supernatant were recovered and frozen until $\mathrm{PCR}^{12}$ analysis.

\section{PCR for enterotoxin genes detection}

Table 1 shows the primers employed for investigating five genes that code for classical enterotoxins ( $s e a, s e b$, sec, sed and see), three coding for new ETs (seg, seh and sei), and the expected molecular weight of the amplicons. The primers sequences and the amplification protocols have been previously described by Manfredi et al. ${ }^{13}$ and after minor modifications, they were applied for searching classical enterotoxin genes. The protocols published by Omoe et al. ${ }^{14}$ were used for investigating the new ET genes. Single reactions were performed for each gene instead of multiplex PCR procedures. The reaction master mix was the same for all genes, combining reagents in a final volume of $25 \mu \mathrm{L}$ with the following concentrations: $0.5 \mu \mathrm{M}$ primers; $0.5 \mathrm{mM}$ dNTPs; $1 \mathrm{X}$ PCR Buffer; 3 $\mathrm{mM} \mathrm{MgCl}$, 1 unit of Taq polymerase and $4 \mu \mathrm{L}$ of DNA template. The following conditions were used for both groups of reactions: an initial denaturation step at $94^{\circ} \mathrm{C}$ for $4 \mathrm{~min}, 30$ cycles of $94{ }^{\circ} \mathrm{C} 60 \mathrm{~s}, 57^{\circ} \mathrm{C} 60 \mathrm{~s}$ and $72{ }^{\circ} \mathrm{C}$ $60 \mathrm{~s}$, and a final extension at $72{ }^{\circ} \mathrm{C}$ for $4 \mathrm{~min}$. Reactions were carried out in a Gene Amp PCR System 2700 thermocycler (Applied Biosystems ${ }^{\circledast}$, California, USA). Amplification products were mixed with $5 \mathrm{X}$ loading buffer, loaded in $1.5 \%$ agarose gels prepared with 0.5 $\mathrm{X}$ Tris-Borate-EDTA (TBE) buffer, and separated by electrophoresis run at $70 \mathrm{~V}$. ATCC 6538 strain carrying 
Table 1 - Primer sequences and amplicon molecular weight in PCRs to detect ET genes.

\begin{tabular}{|c|c|c|c|c|c|}
\hline Primer & $\left(5^{\prime}-3^{\prime}\right)$ sequence & $\begin{array}{c}\text { Amplicon } \\
\text { molecular } \\
\text { weight }\end{array}$ & Primer & $\left(5^{\prime}-3^{\prime}\right)$ sequence & $\begin{array}{c}\text { Amplicon } \\
\text { molecular } \\
\text { weight }\end{array}$ \\
\hline sea $\mathrm{F}$ & GCAGGGAACAGCTTTAGGC & 521 & see $\mathrm{R}$ & CTCTTTGCACCTTACCGC & 121 \\
\hline sea $R$ & GTTCTGTAGAAGTATGAAACACG & & $16 s$ rARN F & GTAGGTGGCAAGCGTTATCC & 228 \\
\hline$s e b \mathrm{~F}$ & ACATGTAATTTTGATATTCGCACTG & 667 & $16 s$ rARN R & CGCACATCAGCGTCAG & \\
\hline$s e b \mathrm{R}$ & TGCAGGCATCATGTCATACCA & & $\operatorname{seg} \mathrm{F}$ & AAGTAGACATTTTTTGGCGTTCC & 287 \\
\hline $\sec \mathrm{F}$ & CTTGTATGTATGGAGGAATAACAA & 284 & $\operatorname{seg} R$ & AGAACCATCAAACTCGTATAGC & \\
\hline $\sec \mathrm{R}$ & TGCAGGCATCATATCATACCA & & $\operatorname{seh} \mathrm{F}$ & GTCTATATGGAGGTACAACACT & 213 \\
\hline sed $\mathrm{F}$ & GTGGTGAAATAGATAGGACTGC & 385 & $\operatorname{seh} \mathrm{R}$ & GACCTTTACTTATTTCGCTGTC & \\
\hline sed $\mathrm{R}$ & ATATGAAGGTGCTCTGTGG & & sei $\mathrm{F}$ & GGTGATATTGGTGTAGGTAAC & 454 \\
\hline see $\mathrm{F}$ & TACCAATTAACTTGTGGATAGAC & 121 & sei $\mathrm{R}$ & ATCCATATTCTTTGCCTTTACCAG & \\
\hline
\end{tabular}

no enterotoxin genes was added to the study as a negative control. Positive controls were obtained from S. aureus strains kindly provided by Dr. E. A. Manfredi (Servicio Fisiopatogenia, Departamento Bacteriologia, Instituto Nacional de Enfermedades Infecciosas - ANLIS "Dr. Carlos G. Malbran" Buenos Aires, Argentina). A PCR mix without DNA for procedure validation, a pair of primers for amplifying the $S$. aureus $16 \mathrm{~S}$ rDNA as internal control, and a 100 bp ladder for comparing amplicon sizes were also included. After staining with $0.3 \mathrm{ug} / \mathrm{ml}$ ethidium bromide, amplicons were visualized with UV light in the FOTO/Analyst investigator Eclipse FOTODYNE* system (Thermo Fisher Scientific, Waltham, MA, USA). The amplified gene type was identified by comparing the obtained molecular weight with known sizes of amplicons shown in tables. ET genes-coding strains were notified to the official agency so that the necessary precautions were taken to protect the population's health.

\section{Amplicon sequencing}

For additional control, the amplicons obtained from two investigated genes (seh and sei) were sequenced. After purifying the DNA with a commercial kit (QIAGEN Inc., Hilden, Germany), the sequencing was performed at the Institut Pasteur of Montevideo. The obtained sequences were compared with those deposited in GenBank using the NCBI BLAST tool (Basic Local Alignment Search Tool).

\section{Pulsed Field Gel Electrophoresis (PFGE)}

A regional standard protocol was followed ${ }^{15}$. Plugs were prepared, a pre-restriction step was performed, and they were then exposed to $S m a \mathrm{I}$ restriction enzyme (New England Biolabs Inc., Ipswich, MA, USA) for $17 \mathrm{~h}$ at $25^{\circ} \mathrm{C}$. The running gel was prepared with ultrapure agarose (Bio-Rad, Hercules, CA, USA, $100 \mathrm{ml}$ ) and $0.5 \mathrm{X}$ TBE buffer. Separation was performed in CHEF-DRII equipment (Bio-Rad, Melville, NY) with the following conditions: initial switching time of $5 \mathrm{~s}$, final switching time of $35 \mathrm{~s}$., $6 \mathrm{~V} / \mathrm{cm}$ or $200 \mathrm{~V}$, running time of $23 \mathrm{~h}$, at $11.3^{\circ} \mathrm{C}$ of temperature and 70 of pump speed. The gel was stained in a $1 \mu \mathrm{g} / \mathrm{mL}$ ethidium bromide solution during $30 \mathrm{~min}$, and visualized as already mentioned. The degree of homology of obtained band patterns was analyzed with the Applied Maths Bionumerics program, using the Dice similarity coefficient with $1.5 \%$ of optimization and $1.5 \%$ of tolerance settings. Two dendrograms were obtained with UPGMA (Unweighted Pair Group Method with Arithmetic Mean). In one of them, only positive isolates for enterotoxin genes were analyzed; all the studied strains were compared in the other one. Each pattern depicts a hierarchical relationship among different isolates. Strains showing a degree of similarity $\geq 95 \%$ were considered identical; if the percentage of similarity of PFGE-types was $\geq 80$, they were considered as belonging to the same PFGE-group or cluster that can include two or more subtypes.

\section{Multilocus sequence typing (MLST)}

Five strains were selected for further analysis by MLST. Extracted DNA was subjected to PCR for the amplification of defined sequences from each of the seven "housekeeping" genes: $\operatorname{arcC}$ (carbamate kinase), aroE (shikimate dehydrogenase), glpF (glycerol facilitator), gmk (guanylate kinase), pta (phosphotransacetylase), tpi (triose phosphate isomerase) and yqiL (acetyl coenzyme A acetyltransferase). Both strands of the DNA amplicons from each of the genes were sequenced using forward and 
reverse primers. The allelic profile and sequence type (ST) of the examined strains were determined by matching their sequences with known MLST sequences from the website. Comparisons were made through BURST analyses of found STs with the regional $S$. aureus types reported on the corresponding pubmlst website, trying to identify groups, relationships, single variants (SV) or double variants (DV).

\section{Resistance genes investigation}

The $m e c A$ gene was investigated in methicillin resistant isolates as previously described ${ }^{16}$; $\operatorname{erm} A, \operatorname{erm} B, \operatorname{erm} C$, $m s r A$ and $m s r B$ were investigated only in macrolidesand lincosamides-resistant isolates. PCR for erm genes were performed in $25 \mu \mathrm{L}$ of reaction master mix with the following composition: $0.8 \mu \mathrm{M}$ of the target sequence primers; $0.2 \mathrm{mM}$ of dNTPs; 1 X PCR Buffer; $\mathrm{MgCl}_{2} 2 \mathrm{mM}$; $1 \mathrm{U}$ of Taq polymerase and $4 \mu \mathrm{L}$ of template DNA. The amplifications conditions were: $94{ }^{\circ} \mathrm{C}$ for $5 \mathrm{~min}, 30$ cycles of $30 \mathrm{~s}$ at $94{ }^{\circ} \mathrm{C}, 50{ }^{\circ} \mathrm{C}$ (for ermA and ermC; $54{ }^{\circ} \mathrm{C}$ for ermB) for $30 \mathrm{~s}$ and $72{ }^{\circ} \mathrm{C}$ for $60 \mathrm{~s}$, and a final extension at $72{ }^{\circ} \mathrm{C}$ during $4 \mathrm{~min}$. The PCR master mix for $m r s A$ and $B$ had a similar reagents composition, excepting for a double $\mathrm{Mg} \mathrm{Cl}_{2}$ concentration. Amplification conditions were: $94{ }^{\circ} \mathrm{C}$ for $5 \mathrm{~min}, 30$ cycles of $94^{\circ} \mathrm{C}$ for $1 \mathrm{~min}, 50^{\circ} \mathrm{C}$ for $1 \mathrm{~min}, 72^{\circ} \mathrm{C}$ for $1.5 \mathrm{~min}$, and a final extension of $10 \mathrm{~min}$ at $72{ }^{\circ} \mathrm{C}^{17}$. Known Streptococcus agalactiae strains carrying these genes were used as positive controls, and a negative sample containing the regular master mix of reagents but without template DNA was used for procedure control. Agarose gel electrophoresis conditions were the same that have already been described.

\section{RESULTS}

\section{Identification of isolates}

The microbiological studies and the positive result of the specific 16S DNA PCR of all the received strains confirmed that they belonged to Staphylococcus aureus species.

\section{Identified enterotoxin genes}

Fifty-two strains $(54.7 \%)$ carried some of the investigated genes. Of these, in $20(38.5 \%)$ a single gene could be detected; 20 isolates carried 2 genes, 9 had 3 genes, 3 yielded 4 genes and one isolate from a food selling store contained 5 enterotoxin-coding genes ( $\mathrm{seb}$, sec, sed, seg and sei) (Table 2). The most frequently found gene, irrespective of the isolate origin (foodstuffs or food premises), was seg, in 31 strains: in six isolates as a single
Table 2 - Type and number of enterotoxin genes found in 52 $S$. aureus isolates.

\begin{tabular}{cccc}
\hline $\begin{array}{c}\text { Gene or } \\
\text { combination } \\
\text { of genes }\end{array}$ & $\begin{array}{c}\text { Number of } \\
\text { isolates }\end{array}$ & Genes & $\begin{array}{c}\text { Number of } \\
\text { isolates }\end{array}$ \\
\hline sea & 2 & sec seg & 3 \\
seb & 1 & see seg & 1 \\
sec & 1 & seg sei & $\underline{5}$ \\
sed & 3 & sea seb sec & 2 \\
see & 2 & sea sed seg & 1 \\
seg & $\underline{6}$ & seb sed seg & 2 \\
seh & 2 & seb seg sei & 2 \\
sei & 2 & sec seg sei & 1 \\
sea seh & 1 & sed seg sei & 2 \\
seb sec & 3 & sec sed seg sei & 2 \\
seb seh & 1 & seb sec seg sei & 1 \\
sed seg & 4 & seb sec sed seg sei & 1 \\
seb sei & 1 & TOTAL & 52 \\
\hline
\end{tabular}

sequence, and in 26 in association with some other one. The second most frequently identified gene was sei, in 17 strains, usually associated with other gene sequences (with a single exception) (Table 3). The most frequent association was sei and $s e g$, found in six isolates. Thirty-eight out of 95 isolates coded for genes of classic enterotoxins, being sed the most frequent of them (Table 3). The outbreak-associated S. aureus isolates cultured from cheese and the store that sold the cheese carried sea, seb and sec DNA sequences.

Table 3 - Number of strains carrying each ET gene, alone or in combinations.

\begin{tabular}{ccc}
\hline Gene & Number of strains & $\%$ \\
\hline sea & 7 & 6.8 \\
seb & 13 & 12.5 \\
sec & 14 & 13.5 \\
sed & 15 & 14.4 \\
see & 3 & 2.9 \\
seg & 31 & 29.8 \\
seh & 4 & 3.8 \\
sei & 17 & 16.3 \\
\hline Total & 104 & 100
\end{tabular}

\section{Sequencing results of seh and sei amplicons}

The sequencing of PCR products from these new enterotoxin genes confirmed that they belonged to seh and sei types. 


\section{Antimicrobial susceptibility}

Almost $90 \%$ of isolates (85/95) were susceptible to all tested antibiotics. Of the remaining $10 \%$, two were resistant to methicillin, carrying the mecA gene; two were only resistant to erythromycin and positive for both $m r s A$ and $m r s B$ genes; the remaining six were resistant to erythromycin with inducible resistance to clindamycin. Two of these six carried the ermA gene, 2 had ermC sequences and the other two had both, the ermB and the erm $C$ genes (Table 4). None of six carried $m r s A$ or $m r s B$ genes. The resistance coding sequences were present in five strains carrying seg and sei or seh genes, but also in five isolates without any ET coding genes.

\section{Pulsed Field Gel Electrophoresis results}

The SmaI enzyme macro restriction generated 9 to 12 bands from each genome. When analyzing the banding patterns of the $52 \mathrm{ET}$ genes- positive isolates, a wide variety was found and more than 20 PFGE-types were defined (Figure 1). Nine clusters with two or more PFGE-types each were identified, including 22 isolates in total. Different gene types were similarly distributed among the analyzed PFGE-types. No specific ET genotype predominated in any defined cluster. It is noteworthy that there is a cluster including the strains carrying many ET genes (one isolate with five genes, one with four genes and one with three gene types).

Two strains, cultured from one cheese and its corresponding grocery, showed the same banding pattern with $100 \%$ matching, and were considered identical, as was another pair of isolates originated in a single food premise and carrying the same ET gene types. When grouping ET coding strains by gene types, banding pattern similarities were lower than $80 \%$.

When examining all of the isolates (with and without ET genes), more than 50 PFGE-types could be defined. There was an outstanding cluster grouping 10 isolates of similar origin, all of them coming from food premises. Most of them (eight out of 10) did not carry any ET coding gene. Somehow, this group showed different susceptibility phenotypes, and the ones sharing resistance characteristics carried different resistance genes. There was a smaller cluster including only five isolates that had also in common the absence of any of the analyzed ET genes; they were all susceptible to all tested antimicrobials, but they did not share a common origin.

\section{MLST results}

Four STs were identified from the five studied isolates: two ST 72, one ST 8, one ST 88 and one newly defined type with a particular allele combination that had not been previously described; it was thus included in the pubmlst database, and ST 3840 was assigned for its identification ${ }^{18}$.

Both ST 72 strains were recovered from food premises: one of them was resistant to methicillin and carried the seg and the sei genes, whereas the other strain was susceptible to methicillin and beared seb, sec sed, seg and sei DNA sequences. The ST 8 strain, derived from foodstuff presumptively involved in a foodborne outbreak, carried

Table 4 - Characteristics of antibiotic-resistant strains and of selected isolates analysed by MLST.

\begin{tabular}{lccccc}
\hline Isolate & Origin & ST & Toxin genes & Susceptibility profile & Resistance genes \\
\hline A 02 & Human handler & -- & seg & MSSA E-Cli & ermA \\
A 08 & Human client & -- & -- & MSSA E-Cli & ermC \\
A 10 & Food & -- & seg, sei & MSSA E & msrA, msrB \\
A 19 & Establishment & -- & -- & MSSA E-Cli & ermB, ermC \\
A 33 & Establishment & -- & -- & MSSA E-Cli & ermA \\
A 39 & Establishment & 88 & seg & MSSA E-Cli & ermB, ermC \\
A51 & Establishment & -- & -- & MRSA & mecA \\
A54 & Food & -- & -- & MSSA E-Cli & ermC \\
A 64 & Food & 3840 & seg & MSSA & -- \\
A 67 & Establishment & 72 & seb, sec, sed, seg, sei & MSSA & -- \\
A 103 & Food & -- & seh & MSSA E & msrA, msrB \\
A 133 & Establishment & 72 & seg, sei & MRSA & mecA \\
A 318 & Cheese & 8 & sea, seb, sec & MSSA & -- \\
\hline
\end{tabular}

MSSA: methicillin-susceptible S. aureus; MRSA: methicillin-resistant S. aureus; E-Cli: erythromycin-resistance plus inducible resistance to clindamycin. 
sea, seb and $\sec$ genes and it was susceptible to all tested antimicrobials. The ST 88 strain came otherwise from a food store, showed inducible resistance to clindamycin, and coded for ET G. Finally, the isolate with the newly assigned

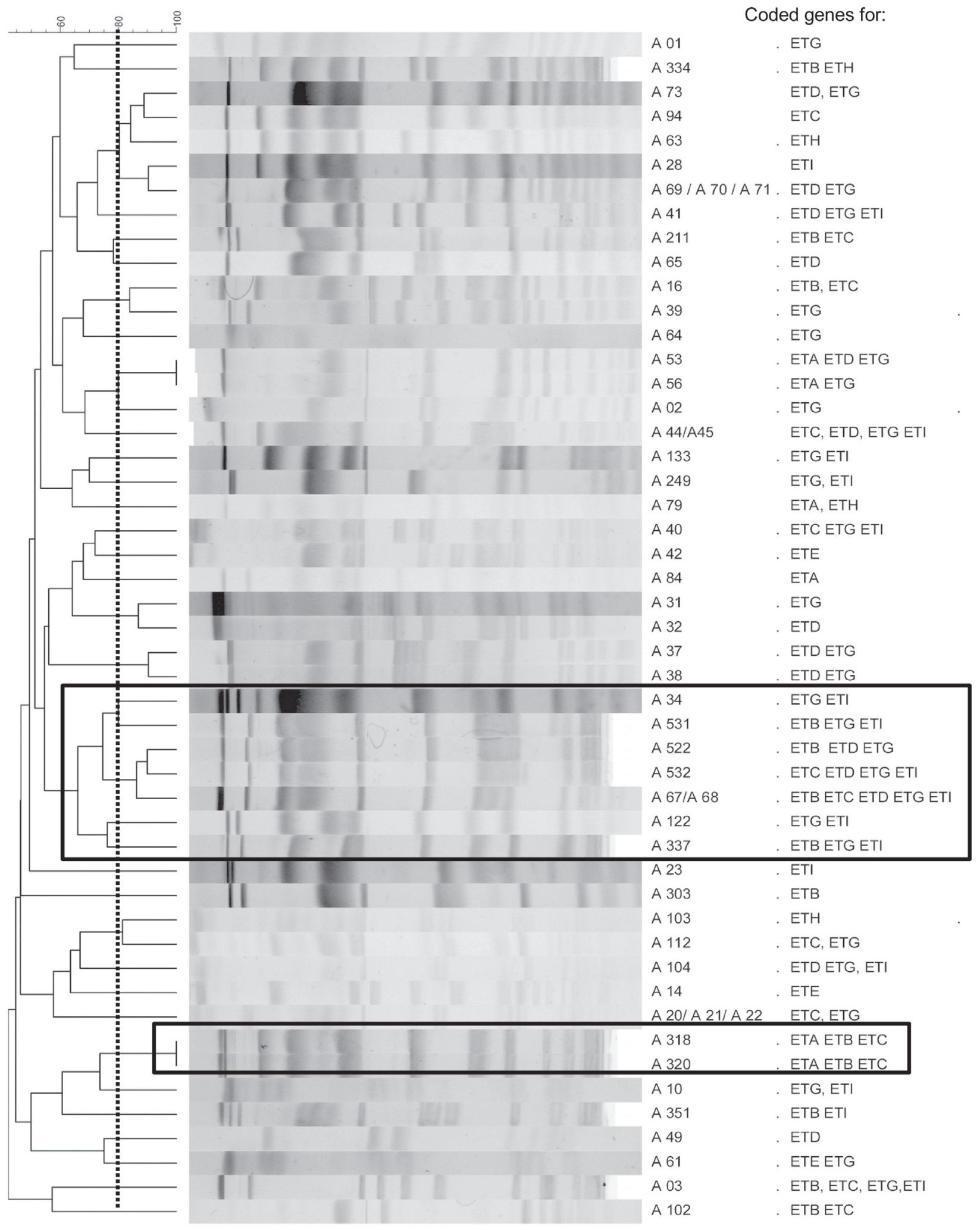

Figure 1 - PFGE profiles of 52 S. aureus isolates that carry ET genes. Dotted line $=80 \%$ homology; Main box = PFGE-group of isolates with multiple enterotoxin genes; Small box = PFGE-group of isolates from a human disease outbreak. 
ST 3840 carried enterotoxin G sequence type and it was susceptible to all tested antibiotics.

\section{DISCUSSION}

Foodborne diseases are important causes of human morbidity and mortality, worldwide. In Uruguay, they are subject to compulsory notification. Staphylococcus aureus has been identified as the second most common cause of foodborne outbreaks, after Salmonella ${ }^{19,20}$. However, established investigation protocols are not usually fulfilled, and medical, epidemiological or laboratory data are frequently missing. Clinical illnesses are usually short, so that patients ignore medical consultations, or medical doctors do not request laboratory exams, hindering the recovery of etiologic agents from outbreaks. This manuscript reports the first systematic investigation of enterotoxins in $S$. aureus isolates obtained from foodstuffs in Uruguay.

Half of the studied bacterial strains were isolated from samples taken from food establishments, from raw material and from food contact surfaces. A similar number was directly cultured from foods. Two closely related isolates were included: one obtained from contaminated cheese, presumptively involved in a small foodborne outbreak, and the second isolate from the corresponding food selling store.

This study found that $54.7 \%$ of examined isolates carried genes coding for some of the studied enterotoxins, and that most of them carried more than one ET gene. These results are novel contributions to the knowledge of Staphylococcus enterotoxins distribution in Uruguay, South America and the world. The diversity of origins and genetic profiles of positive isolates and the presence of $10 \%$ of resistant variants, revealed the potential health risks they represent.

The most frequently found enterotoxin gene was seg (alone or in combination) followed by sei; seg was both prevalent in isolates obtained from foods, and among those recovered from food contact surfaces, tools and raw materials in food establishments. Strains of this last group were more often carriers of ET genes, and coded for more gene types per strain than isolates coming from foodstuffs.

A recent report from South America, performed in Sao Paulo, Brasil, examined more than 2,000 milk samples of bovine mastitis and $285 \mathrm{~S}$. aureus strains, searching for the same enterotoxin genes than we did. The researchers found that the most frequently identified gene was seg, followed by $\mathrm{seh}^{21}$.These findings agree with reports on the presence of $S$. aureus enterotoxins in isolates from foods of different regions of the world. In Ethiopia, 51\% of 160 S. aureus examined isolates from dairy products carried
ET coding genes, being seg and sei the most frequently found, as in our series ${ }^{22}$. An Iranian metanalysis performed in 2017 that included 34 publications on S. aureus strains from contaminated foodstuffs showed that $54 \%$ of them were enterotoxigenic, ranging from 13 to $83 \%$ in different studies. The most frequently found enterotoxins were ETA and ETG among classical and new resistance genes, respectively ${ }^{23}$.In our study, two isolates recovered from a single confirmed outbreak carried sea, seb and sec genes. In published studies of isolates from foodborne outbreaks, classical enterotoxins have been frequently reported as the causes of disease. A recent report from China, including 37 S. aureus isolates recovered in 2015 and 2016 from four foodborne outbreaks, described that 12 strains (32\%) carried enterotoxin genes, being sea the most frequently found ( $81 \%$ ), followed by the combinations sec, se/l and seg, sei, se/m, se/n, selo, selu forming an operon encoded by the enterotoxin gene cluster $2(\operatorname{egc} 2)^{24,25}$. Another study, published in 2015, reviewed 76 staphylococcal foodborne outbreaks occurred in France during the last 30 years. Eleven classical and new genes were investigated in 103 examined strains, of which 87 carried one or more ET coding genes. The most frequent gene was sea, followed by $s e g$ and $s e i^{26}$. Also sea (together with sed) or seb were the classical enterotoxin genes found in $S$. aureus isolates involved in food poisoning outbreaks studied in Argentina ${ }^{27,28}$. Classical and new ET genes were found in an outbreak-associated strain of S. aureus described in Central Italy during a post-earthquake reconstruction ${ }^{29}$. However, several recent outbreak studies reported that the causing agent was Staphylococcus aureus carrying genes of egc cluster (seg, sei, se/m, se/n, se/o and se/u) without classical ET coding genes. All of these outbreaks shared the same clinical case presentation with an early onset of symptoms after consuming a common food, and the identification of a significant number of $S$. aureus colonies, either in the involved food or in the patients' feces. Classical enterotoxins or their coding genes were not found in any examined isolate, in spite of the thorough investigation perfomed by several techniques (PCR, ELISA) ${ }^{30,31}$. These data confirm the importance of new enterotoxins as the cause of foodborne disease, and the need for further research on this subject, especially on the actual presence and concentration of new enterotoxins in foodstuff contaminated with $S$. aureus that carry new ET coding genes. This is not an easy approach, although commercial detection kits are presently available for the detection of classical and even some newly described toxins. Detection rates are influenced by multiple environmental and metabolic parameters, so the identification of toxigenic strains 
in food environments that have not actually produced traceable enterotoxins in foodstuffs or do not produce them in laboratory conditions may still be relevant on epidemiological grounds ${ }^{32,33}$. Regarding the antimicrobial susceptibility of recovered strains, it should be noted that two isolates were resistant to methicillin, other two showed resistance only to erythromycin, and six had the most commonly found resistance profile of resistance to erythromycin and capacity to inducible resistance to clindamycin. Two of these isolates were obtained from human samples, three from food establishments, and one directly from contaminated food. The high antimicrobial susceptibility of most recovered strains could be explained by their origin: although contamination of foods and food establishments can derive from food handlers, it is most often caused by contaminated or poorly preserved raw food materials, which at the moment, do not seem to carry highly resistant strains. In line with our data, international reports described inducible rates of resistance to clindamycin of 3\% or lower in S. aureus obtained from raw milk or derived dairy products ${ }^{34,35}$. This type of resistance has not been extensively studied in local samples of raw foodstuffs of animal origin. However, considering isolates taken in Montevideo, from children's skin and soft tissues infections, inducible resistance to clindamycin was initially described in $30 \%$ of the methicillin-resistant isolates ${ }^{36}$, and a more recent study of $73 \mathrm{~S}$. aureus isolates (most of them susceptible to methicillin), showed that the prevalence of this resistance has declined to only $4 \%$, a similar rate to the frequency observed in isolates of the present study ${ }^{37}$ Both MRSA isolates harbored $m e c A$, which is an important observation because methicillin-resistant strains bearing the mecC genotype have been increasingly described in association with bovine mastitis, animal carriage and human diseases related to occupational exposure ${ }^{38}$. SmaIPFGE defined a higher number of PFGE-types in nonenterotoxigenic strains than among ET gene positive ones. Not surprisingly, there was no predominant PFGE-type among the studied isolates. The large number and diversity of the patterns (more than 50 types) could be explained by the varied and independent origin of isolates and by the extended period of sampling. However, some clusters could be defined, and the collection of gathered molecular data on the locally circulating strains in foods and food establishments may constitute the basis for comparison in future surveillance studies, or in new $S$. aureus foodborne outbreaks studies. Special attention should be paid to the mentioned group of potentially pathogenic isolates that harbour numerous ET genes.

MLST is a trustworthy classification tool, because it is based on sequencing of seven highly conserved genes, providing information on the lineage of examined strains, broadening our understanding on the long-term epidemiology of staphylococci or other bacteria. The obtained data can be easily shared by different laboratories as there is a wide online database that contains the allelic profile of thousands of strains, helping the unification, standardization and interpretation of results.The five $S$. aureus isolates subjected to MLST were selected for having some special characteristics. The first one was the strain associated with a small outbreak, that beared $s e a, s e b$ and $s e c$ genes. The other four isolates carried seg, the most frequently found ET gene. One of them coded for four additional enterotoxins, another one was methicillinresistant, and the other two were susceptible to methicillin, but one of them was resistant to erythromycin and showed an inducible clindamycin resistance. Our MRSA was ST 72 and carried seg and sei genes, as did MRSA isolates from foods studied in Asian countries ${ }^{23,39}$, but the second ST 72 strain was susceptible to antimicrobials and coded for three additional enterotoxins. ST 8 and ST 72 strains from neighbouring South American countries (Argentina, Brasil, Chile, Paraguay) and the prevalent ST8 USA300 had already been recorded in pubmlst database. They were both founder types of group 2 (they shared at least five alleles). The new ST 3840 is part of group 5 and is a SV of founder ST 15, differing only in their $p t a$ allele. ST 88 strains other than ours have not been included in pubmlst database by other South American countries. When selecting outbreak-associated strains, regardless of their geographical origin for BURST analyses, ST 88 from Vietnam and several ST 72 isolates from South Korea and Vietnam were found, revealing the potential pathogenic role of these locally circulating types. Isolate $\mathrm{A}$ 133 (ST 72, seg and sei positive, MRSA) seems very similar to the prevalent Korean clone described in association with food-borne disease ${ }^{39}$.

The frequent presence of enterotoxin coding genes in $S$. aureus strains from foostuffs, raw food materials and establishments, and the identification of one of these strains in association with a foodborne outbreak are facts that have not been previously documented in our country. They are a matter of concern regarding the safety of commonly consumed foods. They also reveal the need for a routine surveillance and diagnostic procedures to evaluate and avoid the risks of disease caused by classic enterotoxins as well as by new enterotoxins that are often recognized as potential food contaminants. Further research is needed and would benefit from the improvement of sample gathering of confirmed outbreaks, through a better education of clinicians, health staff, laboratory workers and the general population so as to optimize the diagnosis, recovery and characterization of relevant $S$. aureus isolates. 


\section{ACKNOWLEDGMENTS}

To Eduardo Manfredi of the Bacteriology Department, National Institute of Infectious Diseases Dr. "Carlos G. Malbran", Argentina, and Marta Mollerach, Microbiology Department, Faculty of Biochemistry and Pharmacy, University of Buenos Aires. They allowed VM internships, providing training and technical support. To Marcela Legnani from the Food Microbiology Laboratories of Montevideo local government, for providing many food isolates. This work was partially supported by CSIC-UdelaR (University Research Bureau - research groups program, grant $\left.\mathrm{N}^{\circ} 290,2011-2014\right)$ and by ANII (National Agency for Research and Development) with a research scholarship for Virginia Machado.

\section{REFERENCES}

1. Kirk MD, Pires SM, Black RE, Caipo M, Crump JA, Devleesschauwer B, et al. World Health Organization estimates of the global and regional disease burden of 22 foodborne bacterial, protozoal, and viral diseases, 2010: a data synthesis. PLoS Med. 2015;12:e1001921.

2. Larkin EA, Carman RJ, Krakauer T, Stiles BG. Staphylococcus aureus: the toxic presence of a pathogen extraordinaire. Curr Med Chem. 2009;16:4003-19.

3. Dinges MM, Orwin PM, Schlievert PM. Exotoxins of Staphylococcus aureus. Clin Microbiol Rev. 2000;13:16-34.

4. Bhatia A, Zahoor S. Staphylococcus aureus Enterotoxins: a review. J Clin Diagn Res. 2007;3:188-97.

5. Bergdoll MS, Crass BA, Reiser RF, Robbins RN, Davis JP. A new staphylococcal enterotoxin, enterotoxin $\mathrm{F}$, associated with toxic-shock-syndrome Staphylococcus aureus isolates. Lancet. 1981;1:1017-21.

6. Viçosa GN, Le Loir A, Le Loir Y, Carvalho AF, Nero LA. egc characterization of enterotoxigenic Staphylococcus aureus isolates obtained from raw milk and cheese. Int J Food Microbiol. 2013;165:227-30.

7. Monday SR, Bohach GA. Genes encoding staphylococcal enterotoxins $\mathrm{G}$ and I are linked and separated by DNA related to other staphylococcal enterotoxins. J Nat Toxins. 2001;10:1-8.

8. Koymans KJ, Vrieling M, Gorham RD Jr, van Strijp JA. Staphylococcal immune evasion proteins: structure, function, and host adaptation. In: Bagnoli F, Rappuoli R, Grandi G, editors. Staphylococcus aureus: microbiology, pathology, immunology, therapy and prophylaxis. Geneva: Springer International; 2017. p.441-89.

9. MacFaddin JF. Pruebas bioquímicas para la identificación de bacterias de importancia clínica. $3^{\mathrm{a}}$ ed. Buenos Aires: Panamericana; 2003.

10. Clinical and Laboratory Standards Institute. Performance standards for antimicrobial susceptibility testing: twenty-fourth informational supplement. Wayne: CLSI; 2014.

11. Steward CD, Raney PM, Morrell AK, Williams PP, McDougal LK, Jevitt L, et al. Testing for induction of clindamycin resistance in erythromycin-resistant isolates of Staphylococcus aureus. J Clin Microbiol. 2005;43:1716-21.

12. Paule SM, Pasquariello AC, Hacek DM, Fisher AG, Thomson RB Jr, Kaul KL, et al. Direct detection of Staphylococcus aureus from adult and neonate nasal swab specimens using real-time polymerase chain reaction. J Mol Diagn. 2004;6:191-6.

13. Manfredi EA, Leotta GA, Rivas M. PCR múltiple para la detección de los genes sea, seb, sec, sed y see de Staphylococcus aureus. Caracterización de aislamientos de origen alimentario. Rev Argent Microbiol. 2010;42:212-5.

14. Omoe K, Ishikawa M, Shimoda Y, Hu DL, Ueda S, Shinagawa K. Detection of seg, seh, and sei genes in Staphylococcus aureus isolates and determination of the enterotoxin productivities of S. aureus isolates harboring seg, seh or sei genes. J Clin Microbiol. 2002;40:857-62.

15. Bannerman TL, Hancock GA, Tenover FC, Miller JM. Pulsed-field gel electrophoresis as a replacement for bacteriophage typing of Staphylococcus aureus. J Clin Microbiol. 1995;33:551-5.

16. Fey PD, Saïd-Salim B, Rupp ME, Hinrichs SH, Boxrud DJ, Davis $\mathrm{CC}$, et al. Comparative molecular analysis of community- or hospital-acquired methicillin-resistant Staphylococcus aureus. 2003;47:196-203.

17. Lina G, Quaglia A, Reverdy M, Leclercq R, Vandenesch F, Seienne J. Distribution of genes encoding resistance to macrolides, lincosamides, and streptogramins among staphylococci. Antimicrob Agents Chemother. 1999;43: 1062-6.

18. Public Database for Molecular Typing and Microbial Genome Diversity. Full information on isolate A64 (id:32227). [cited 2019 Dec 10]. Available from: https://pubmlst.org/ bigsdb?page $=$ info\&db=pubmlst_saureus_isolates\&id=32227

19. Palacio R, Sirok A, Alfonso A, Legnani M, Silva A, Castro M, et al. Vigilancia de las enfermedades trasmitidas por alimentos en Uruguay, período 2000-2009. In: 20 ${ }^{\text {th }}$ Latin American Microbiology Congress; 2010 Sep 27-30; Montevideo, Uruguay.

20. Uruguay. Ministerio de Salud Pública. Dirección General de la Salud. División Epidemiología. Boletín epidemiológico: mayo 2017. [cited 2019 Dec 10]. Available from: https://www.gub. uy/ministerio-salud-publica/comunicacion/publicaciones/ boletin-epidemiologico-mayo-2017

21. Bonsaglia EC, Silva NC, Rossi BF, Camargo CH, Dantas ST, Langoni $\mathrm{H}$, et al. Molecular epidemiology of methicillinsusceptible Staphylococcus aureus (MSSA) isolated from milk of cows with subclinical mastitis. Microb Pathog. 2018;124:130-5.

22. Tarekgne EK, Skjerdal T, Skeie S, Rudi K, Porcellato D, Félix B, et al. Enterotoxin gene profile and molecular characterization of Staphylococcus aureus isolates from bovine bulk milk and 
milk products of Tigray region, northern Ethiopia. J Food Prot. 2016;79:1387-95.

23. Karimi Dehkordi M, Ghasemi Shamsabadi M, Banimehdi P. The occurrence of Staphylococcus aureus, enterotoxigenic and methicillin-resistant strains in Iranian food resources: a systematic review and meta-analysis. Ann Ig. 2019;31:263-78

24. Chen Q, Xie S. Genotypes, enterotoxin gene profiles and antimicrobial resistance of Staphylococcus aureus associated with foodborne outbreaks in Hangzhou, China. Toxins (Basel). 2019;11:E307.

25. Argudín MA, Mendoza MC, Rodicio MR. Food poisoning and Staphylococcus aureus enterotoxins. Toxins (Basel). 2010;2:1751-73.

26. Roussel S, Felix B, Vingadassalon N, Grout J, Hennekinne JA, Guillier L, et al. Staphylococcus aureus strains associated with food poisoning outbreaks in France: comparison of different molecular typing methods, including MLVA. Front Microbiol 2015;6:882.

27. Brizzio AA, Tedeschi FA, Zalazar FE. Estrategia de PCR múltiple para la caracterización molecular simultánea de Staphylococcus aureus y enterotoxinas estafilocócicas en aislamientos de brotes de origen alimentario. Biomedica 2013;33:122-7.

28. Manfredi EA, Rivas M. Brote de intoxicación alimentaria en un jardín de infantes de la provincia de Buenos Aires. Rev Argent Microbiol. 2019;51:354-8.

29. Guidi F, Duranti A, Gallina S, Nia Y, Petruzzelli A, Romano A, et al. Characterization of a staphylococcal food poisoning outbreak in a workplace canteen during the post-earthquake reconstruction of Central Italy. Toxins (Basel). 2018;10:E523.

30. Umeda K, Nakamura H, Yamamoto K, Nishina N, Yasufuku K, Hirai Y, et al. Molecular and epidemiological characterization of staphylococcal foodborne outbreak of Staphylococcus aureus harboring seg, sei, sem, sen, seo, and selu genes without production of classical enterotoxins. Int J Food Microbiol. 2017;256:30-5
31. Johler S, Giannini P, Jermini M, Hummerjohann J, Baumgartner A, Stephan R. Further evidence for staphylococcal food poisoning outbreaks caused by egc-encoded enterotoxins. Toxins (Basel). 2015;7:997-1004.

32. Schelin J, Susilo YB, Johler S.Expression of staphylococcal enterotoxins under stress encountered during food production and preservation. Toxins (Basel). 2017;9:E401.

33. Zeaki N, Johler S, Skandamis PN, Schelin J. The role of regulatory mechanisms and environmental parameters in staphylococcal food poisoning and resulting challenges to risk assessment. Front Microbiol. 2019;10:1307.

34. Cho YS, Lee MK, Hwang SH. Toxin gene profiles, genetic diversity, antimicrobial resistance and coagulase type of Staphylococcus aureus from cream filled bakery products. Food Sci Nutr. 2019;28:1727-34

35. Jamali H, Paydar M, Radmehr B, Ismail S, Dadrasnia A. Prevalence and antimicrobial resistance of Staphylococcus aureus isolated from raw milk and dairy products. Food Control. 2015;54:383-8.

36. Pardo L, Vola M, Macedo-Viñas M, Machado V, Cuello D, Mollerach M, et al. Community-associated methicillinresistant Staphylococcus aureus in children treated in Uruguay. J Infect Dev Ctries. 2013;7:10-6.

37. Batalla D, Maldonado F, Panfilo F, Rivero V, Sierra N, Pardo $\mathrm{L}$, et al. Caracterización de las infecciones de piel y tejidos blandos en niños de 0 a 14 años asistidos en el Departamento de Emergencia Pediátrica del Centro Hospitalario del Pereira Rossell en el 2014. AnFaMed. 2016;3 Supl 1:83-9.

38. Vindel A, Cercenado E. Staphylococcus aureus resistentes a la meticilina portadores del gen mecC: ¿un problema emergente? Enferm Infecc Microbiol Clin. 2016;34:277-9.

39. Shin E, Hong H, Park J, Oh Y, Jung J, Lee Y. Characterization of Staphylococcus aureus faecal isolates associated with foodborne disease in Korea. J Appl Microbiol. 2016;121:27786. 